\title{
Posttranslational Modification of p53: Cooperative Integrators of Function
}

\author{
David W. Meek ${ }^{1}$ and Carl W. Anderson ${ }^{2}$ \\ ${ }^{1}$ Biomedical Research Institute, Ninewells Hospital and Medical School, University of Dundee, Dundee \\ DD1 9SY, United Kingdom \\ ${ }^{2}$ Department of Biology, Brookhaven National Laboratory, Upton, New York 11973 \\ Correspondence: d.w.meek@dundee.ac.uk
}

The p53 protein is modified by as many as 50 individual posttranslational modifications. Many of these occur in response to genotoxic or nongenotoxic stresses and show interdependence, such that one or more modifications can nucleate subsequent events. This interdependent nature suggests a pathway that operates through multiple cooperative events as opposed to distinct functions for individual, isolated modifications. This concept, supported by recent investigations, which provide exquisite detail as to how various modifications mediate precise protein-protein interactions in a cooperative manner, may explain why knockin mice expressing p53 proteins substituted at one or just a few sites of modification typically show only subtle effects on p53 function. The present article focuses on recent, exciting progress and develops the idea that the impact of modification on p53 function is achieved through collective and integrated events.

\section{INTRODUCTION AND HISTORICAL PERSPECTIVE}

$\mathrm{T}_{\mathrm{p}}^{\mathrm{h}}$ he p53 tumor suppressor was shown to be a phosphoprotein (Jenkins et al. 1984; Lane 1992) shortly after its discovery (first as an oncoprotein) 30 years ago by three independent groups, and the first phosphorylated sites, Ser312 and Ser389 in mouse p53, were identified soon thereafter (Samad et al. 1986). These early studies involved analyses by thin-layer chromatography of radioactive peptides of p53 from transformed rodent cells in which p53 was stabilized through its interaction with a DNA tumor virus antigen such as the SV40
T-antigen (Meek and Eckhart 1988) and/or by automated Edman sequence analysis of radiolabeled p53 peptides to infer the site(s) of phosphorylation. In some cases, it could be shown that a known, purified serine/threonine kinase was capable of phosphorylating p53 in vitro, but demonstrating that a specific kinase phosphorylated p53 in vivo was extremely difficult, as was showing that phosphorylation changed the functional properties of p53. Nevertheless, steady progress was made through the late 1980s and early 1990s toward overcoming these hurdles.

Interest in p53 posttranslational modifications (PTMs) increased dramatically in response

Editors: Arnold J. Levine and David Lane

Additional Perspectives on The p53 Family available at www.cshperspectives.org

Copyright (C) 2009 Cold Spring Harbor Laboratory Press; all rights reserved; doi: 10.1101/cshperspect.a000950

Cite this article as Cold Spring Harb Perspect Biol 2009;00:a000950 
to several reports. A role for p53 in transcription was proposed in 1990 on the basis of studies in yeast, and subsequently p53 was shown to have sequence-specific DNA binding activity (reviewed in Lane 1992). In 1991, Kastan and colleagues (Kastan et al. 1991) showed that p53 protein levels increased in response to the exposure of cells to DNA damageinducing agents, and that the increase correlated with the inhibition of cell cycle progression. In 1992, Lees-Miller et al. (Lees-Miller et al. 1992) showed that the DNA-activated protein kinase, DNA-PK, phosphorylated p53 in vitro on Ser15 and Ser37 in the amino-terminal transactivation domain. Hupp et al. (Hupp et al. 1992) subsequently proposed an allosteric model for p53 activation as a DNA binding protein because of posttranslational modifications at its carboxyl terminus. Thereafter, it was reported that phosphorylation of Ser15 induced the dissociation of MDM2 from p53, which resulted in p53 stabilization (Shieh et al. 1997). These were the first hypothesized functional roles for p53 PTMs, and, whereas we now know that the mechanisms are more complex (as described later), the suggestions from these early studies were important in establishing a strong interest in characterizing p53 PTMs.

The development of site-specific antibodies that recognized p53 only when modified at a specific site greatly simplified the analysis of PTMs and led to rapid advances. More recently, mass spectrometry has facilitated the identification of additional PTMs, and the catalog of p53 PTMs now comprises modifications to approximately 50 sites throughout the polypeptide and includes phosphorylation, acetylation, mono- and di-methylation, glycosylation, ubiquitylation, neddylation, sumolyation, and poly-ribosylation (summarized in Fig. 1). The catalog of p53 PTMs has been extensively reviewed (Meek 1999; Appella and Anderson 2001; Bode and Dong 2004; Toledo and Wahl 2006; Olsson et al. 2007; Anderson and Appella 2009) and now is possibly nearly complete. In most cases, however, the functional roles of these modifications and knowledge of the signaling pathways that lead to them are far from well understood.
The purpose of the present article is to focus on selected recent advancements that have elevated our understanding of how these modifications function mechanistically to regulate key events in p53 biology. Accordingly, we identify four aspects of recent research that are at the forefront of this area. These are: (1) the cooperative role of amino-terminal phosphorylation events in regulating interactions of p53 with the p53 inhibitor MDM2 or the transcriptional coactivator proteins p300 (KAT3B) and CBP (KAT3A); (2) the function of growth factor-mediated phosphorylation in coordinating physiological and developmental signals; (3) the critical involvement of acetylation events in selectively stimulating p53-dependent transactivation; and (4) the growing awareness of the importance of demodifying enzymes in providing acutely sensitive mechanisms for controlling p53 function. These studies highlight a striking level of complexity, cooperation, coordination, integration, and specificity underpinning a rapid, reversible, and highly sensitive system that is exquisitely selective in meeting the needs of the cell according to the type and intensity of the stimuli that bear on its biological status.

\section{THE SEQUENTIAL AND INTERDEPENDENT CHARACTER OF p53 POSTTRANSLATIONAL MODIFICATIONS}

Many phosphorylation events on p53 are stimulated by a variety of genotoxic and nongenotoxic agents (Anderson and Appella 2009), but there are significant differences in the degree of modification of different residues achieved using different stress-inducing agents (for example, see Saito et al. 2003). There is little evidence for any phosphorylation of p53 following induction through the ARF pathway (de Stanchina et al. 1998), although acetylation of p53 has been reported during this event (Ito et al. 2001; Mellert et al. 2007). Strikingly, the phosphorylation of Ser 15 (mediated principally by the ATM and ATR protein kinases in response to genotoxic stress) acts as a nucleation event that promotes or permits subsequent sequential modification of many 
p53 Posttranslational Modifications

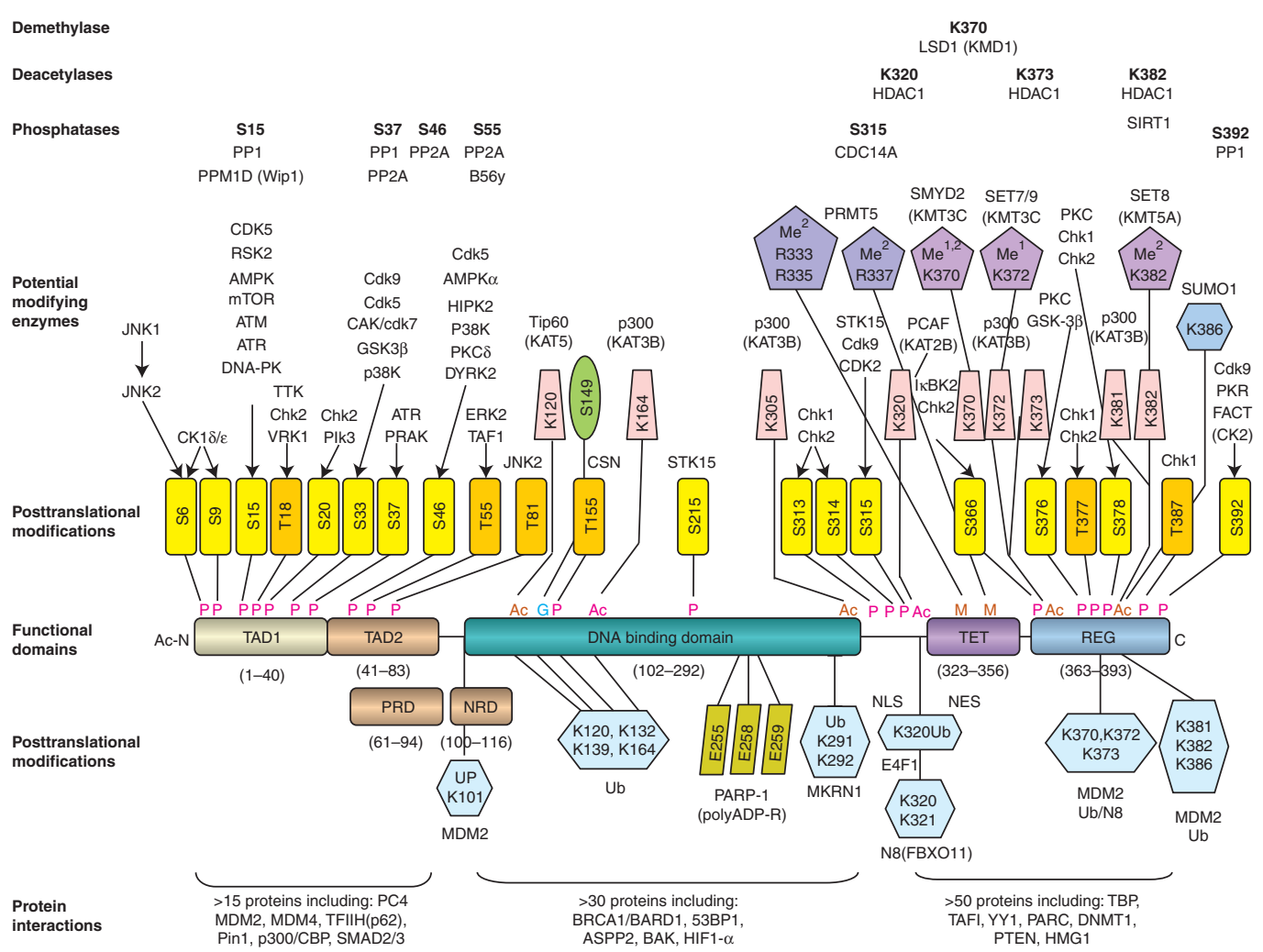

Figure 1. Posttranslational modification of human p53. The figure is updated from Anderson and Appella (Anderson and Appella 2009). The principal functional domains of p53 are shown together with the sites of modification and their potential modifying and demodifying enzymes.

residues (Sakaguchi et al. 1998; Sakaguchi et al. 2000; Saito et al. 2002; Saito et al. 2003), and cells lacking functional ATM fail to modify efficiently serines $9,15,20$, and 46 in particular (Saito et al. 2002). Additionally and importantly, ATM-initiated phosphorylation promotes the recruitment of histone/lysine acetyltransferases (HAT), such as p300 and CBP (Lambert et al. 1998; Dumaz and Meek 1999; Dornan and Hupp 2001; Polley et al. 2008; Feng et al. 2009; Jenkins et al. 2009; Lee et al. 2009a; Teufel et al. 2009), leading to acetylation of multiple lysine residues in the DNA binding (DBD) and carboxy-terminal domains of p53. These modifications are thought to contribute to the stabilization of p53 by blocking ubiquitylation (Sakaguchi et al. 1998; Ito et al. 2002), or to modulating binding of p53 to specific response elements (detailed later).
Ser15 is also phosphorylated through the AMPK (AMP-activated protein kinase) pathway in response to glucose depletion and mediates a p53-dependent metabolic arrest at G1/S (Jones et al. 2005), although it is unclear whether AMPK itself modifies Ser 15 directly. Nevertheless, this is a milestone discovery demonstrating that Ser15 phosphorylation is a critical focal point for cellular stresses that are independent of DNA damage.

\section{THE INDUCTION AND ACTIVATION OF p53}

p53 is rapidly turned over in normal unstressed cells mainly through the action of MDM2, a RING finger type E3 ligase that promotes the poly-ubiquitylation and proteasomal degradation of p53, and additionally inhibits p53-mediated transactivation. MDM2 is critical for maintaining p53 levels, both in developing 
D.W. Meek and C.W. Anderson

and in adult mice (Jones et al. 1995; Montes de Oca Luna et al. 1995; Ringshausen et al. 2006). However, several other p53-targeted ubiquitin ligases, including Pirh2, COP1, CHIP, ARFBP1, E6-AP, TOPORS, TRIM24 (Allton et al. 2009), and MKRN1 (Lee et al. 2009b) also contribute to p53 turnover (Brooks and Gu 2006). The main p53 targets of MDM2-mediated ubiquitylation are the six carboxy-terminal lysines (K370, K372, K373, K381, K382, and K386) (Rodriguez et al. 2000).

Induction of p53 involves uncoupling it from its negative regulators, principally MDM2 and the related protein MDM4, which, like MDM2, inhibits p53-mediated transactivation (Marine et al. 2007). Posttranslational modification of p53 plays a key role in this process, at least in the context of the DNA damage response (see later). A complementary, but not mutually exclusive, model is that MDM2 itself is a key target of the various stress signaling pathways that impinge on $\mathrm{p} 53$. Thus, inhibition and/or rapid degradation of MDM2 and MDM4 have also been proposed to lead to a rapid accumulation of p53 and activation of its transcription functions (reviewed in Toledo and Wahl 2006; Meek 2009).

\section{FUNCTIONAL AND SYNERGISTIC ROLE OF AMINO-TERMINAL PHOSPHORYLATION IN REGULATING ASSOCIATION WITH p300/ CBP AND MDM2}

The closely related transcriptional coactivator proteins p300 and CBP each assume a dual role in regulating p53 function. On the one hand, they promote the ubiquitylation and turnover of p53 by MDM2 (Grossman et al. 1998; Grossman et al. 2003) while having critical roles in mediating p53-dependent transactivation in response to genotoxic stress (Avantaggiati et al. 1997; Gu et al. 1997; Lill et al. 1997), and both act to modify histones and open up promoter regions to the core transciptional apparatus (Espinosa and Emerson 2001). They also inhibit p53 degradation by acetylating lysine residues in the carboxyl terminus of p53 that are normally targets for ubiquitylation. p300 and CBP contain multiple domains including regions important for protein-protein interaction and HAT activity. p53 binds to each of four structurally similar domains within p300/CBP: Taz1, Kix, Taz2, and IbiD (Avantaggiati et al. 1997; Gu et al. 1997; Grossman et al. 1998; Van Orden et al. 1999; Livengood et al. 2002; Teufel et al. 2007). Indeed, Teufel et al. proposed a "wrap-around" model wherein each of these four p53-binding domains in the p300 monomer interacts with an individual subunit of the p53 tetramer (Teufel et al. 2007) (Fig. 2).

The transactivation domain of p53 falls into two distinct structurally similar subdomains termed TAD1 (residues 1-40) and TAD2 (4183) (Fig. 1). Although these domains each bind independently to p300/CBP to mediate transcription (Chang et al. 1995; Candau et al. 1997), they bind simultaneously to distinct interacting surfaces within a single p300/CBP domain (for example, KIX [Lee et al. 2009a]) and act synergistically within the context of the full length p53 molecule (Fig. 3) (Teufel et al. 2007; Ferreon et al. 2009; Lee et al. 2009a; Teufel et al. 2009). Additionally, TAD2 forms a relatively tighter association with the Taz2 domain than does TAD1 (Ferreon et al. 2009). This arrangement supports formation

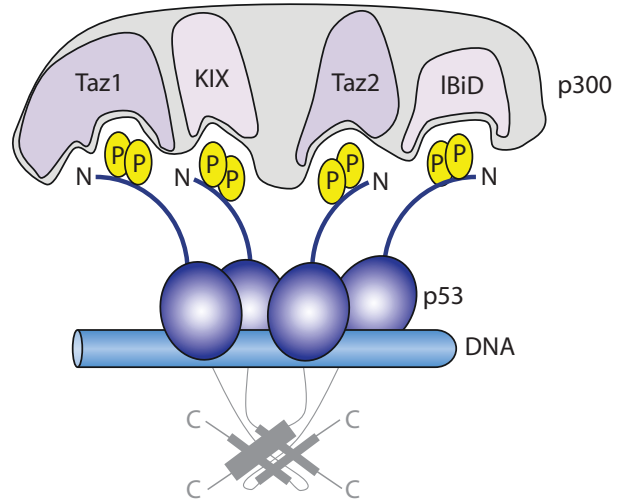

Figure 2. Multisite phosphorylation of the amino terminus of $\mathrm{p} 53$ regulates the interaction with MDM2 and with p300/CBP. "Wrap around" model proposed by Fersht and colleagues (Teufel et al. 2007) for the simultaneous binding of one monomer of p300/CBP to tetrameric p53. These interactions are stimulated by multisite phosphorylation of the amino terminus of p53. 


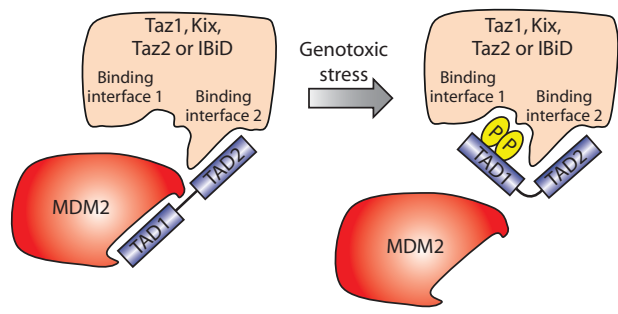

Figure 3. Mutually exclusive binding of MDM2 and p300/CBP to p53. Four similar subdomains of p300 (Taz1, Taz2, Kix, and IBiD) can each simultaneously bind to the TAD1 and TAD2 transactivation subdomains of p53. Binding to TAD2 is essentially phosphorylation-independent but multisite phosphorylation within TAD1 greatly stimulates its interaction with p300 but blocks association with MDM2. p300 acts as a scaffold in mediating MDM2-dependent ubiquitylation and degradation of p53: Concurrent binding of MDM2 to TAD1 and p300 to TAD2 may facilitate p53 turnover.

of a ternary complex in which TAD2 interacts with one of the p300/CBP domains, whereas TAD1 from the same p53 molecule simultaneously interacts with MDM2. This ternary complex is thought to promote ubiquitylation and degradation of p53 and fits with earlier data highlighting a role for $\mathrm{p} 300$ in this process (Grossman et al. 1998; Grossman et al. 2003). In this model, the ability of MDM2 and TAD1 to compete for binding to $\mathrm{p} 300 / \mathrm{CBP}$ determines whether the outcome will be p53 degradation assisted by $\mathrm{p} 300 / \mathrm{CBP}$ or the assembly of active transcriptional complexes.

Given these two seemingly contradictory roles for p300/CBP, how might these be resolved? Several studies have now provided compelling evidence that multisite aminoterminal phosphorylation of p53 has a profound influence on the interaction of $\mathrm{p} 53$ with p300/CBP and may mediate the switch between ternary complex formation with MDM2 and full association with p300/CBP. Earlier studies revealed that phosphorylation of amino-terminal sites in p53, including Ser15, Thr18, and Ser20, increases the association of p53 with p300/CBP and stimulates p53 transactivation function (Lambert et al. 1998; Dumaz and Meek 1999; Dornan et al.
2003; Finlan and Hupp 2004). Additionally, phosphorylation of these residues was shown to block MDM2 binding and to lead to decreased turnover of p53 (Shieh et al. 1997; Böttger et al. 1999; Chehab et al. 1999; Craig et al. 1999; Dumaz et al. 1999; Unger et al. 1999; Sakaguchi et al. 2000; Dumaz et al. 2001; Schon et al. 2002). These studies suggested a dual role whereby amino-terminal phosphorylation could act as a switch by simultaneously promoting p53-mediated transactivation and uncoupling its inhibition by MDM2. Recently, biophysical analyses, using a range of phosphorylated amino-terminal peptides, have shown that phosphorylation of individual residues (Ser15, -20, -33, -37, -46, -55, and Thr18) stimulates, to various degrees, the interaction of these with each of the four p53-binding sites on p300/CBP (Polley et al. 2008; Feng et al. 2009; Ferreon et al. 2009; Jenkins et al. 2009; Lee et al. 2009a; Teufel et al. 2009). All authors agree that, among these residues, Thr18 phosphorylation has the most potent impact. Moreover, di- or multiple phosphorylation events can act cooperatively, increasing the $\mathrm{p} 53 / \mathrm{p} 300$ interaction by as much as 80 -fold, although the extent to which this occurs varies among the different studies. Additionally, the association of TAD1 with MDM2 is significantly weakened by phosphorylation of Thr18 (Ferreon et al. 2009; Teufel et al. 2009). Interestingly, although other amino-terminal phosphorylation events have little influence on MDM2 binding individually, phosphorylation of all seven amino-terminal sites inhibits such binding to MDM2 by four times as much as does phosphorylation of Thr18 alone (Teufel et al. 2009). This evidence supports a mechanism whereby differential phosphorylation events mediated by differences in the type and intensity of the stress, and the cell type, not only fine-tune the affinity of the p53-p300/CBP interaction and consequently the transcriptional outcome but also collectively constitute a potent regulatory switch favoring TAD1 binding to $\mathrm{p} 300 / \mathrm{CBP}$ over its interaction with MDM2 (Fig. 4).

In addition to these biophysical analyses, resolution of the structure of the Taz2 domain 
D.W. Meek and C.W. Anderson
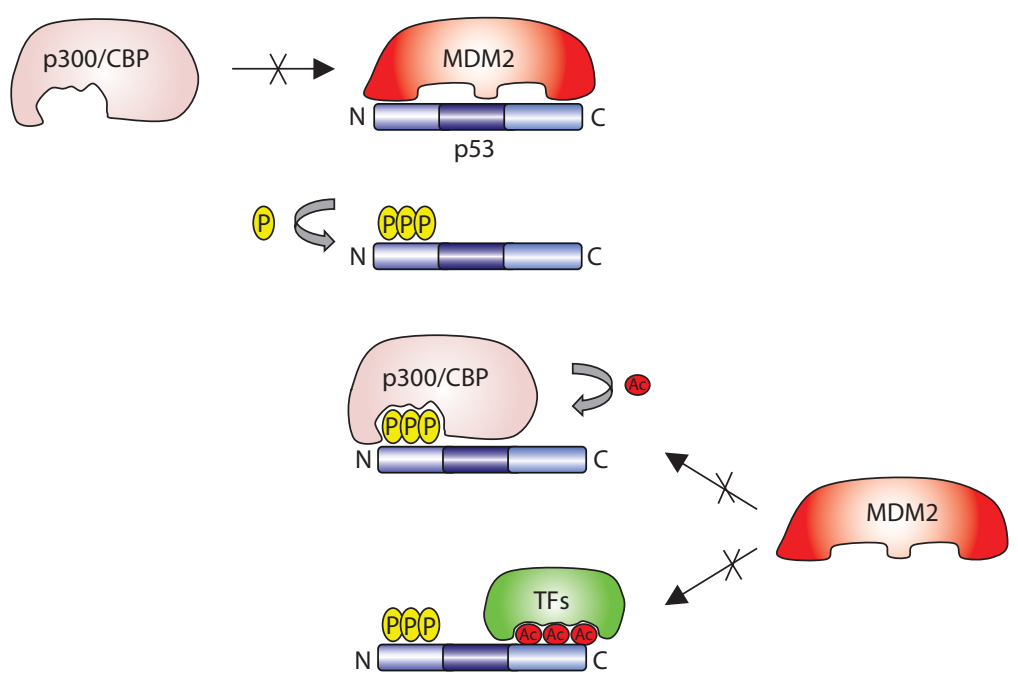

Figure 4. Sequential multiple modifications may act as a switch that excludes MDM2 binding in favor of interaction with transcriptional proteins. Multisite phosphorylation of the amino terminus of p53 blocks the interaction with MDM2 and favors recruitment of the HATs p300 and CBP that subsequently can acetylate numerous lysine residues in p53, further adding to the exclusion of MDM2 and favoring the engagement of transcriptional components.

in complex with the TAD1 peptide of p53 has provided significant insight into the molecular interactions mediating p53-p300 association and suggests that phosphorylation of Ser 15 and particularly of Thr 18 increases electrostatic interactions with specific arginine residues in the Taz2 domain, thereby strengthening the interaction (Feng et al. 2009).

Although phosphorylation events within the TAD1 domain can clearly mediate p53Mdm2-p300/CBP interactions, phosphorylation of sites within TAD2 seems to have little effect on p300 binding (Jenkins et al. 2009; Teufel et al. 2009). It is likely, however, that these modifications play a different role in p53-mediated transactivation. The TAD2 region of p53 also interacts with other proteins, such as the p62 subunit of the general transcription factor TFIIH, an interaction that is important for p53-stimulated transcriptional events following relaxation of the chromatin structure within the promoter region. Phosphorylation of Ser46, a target of p38 MAPK (Bulavin et al. 1999; Perfettini et al. 2005), HIPK2 (D'Orazi et al. 2002; Hofmann et al. 2002; Möller et al. 2003; Dauth et al. 2007), DYRK2 (Taira et al. 2007), and possibly other kinases, and of Thr55, which is phosphorylated by the TAF1 $\left(\mathrm{TAF}_{\mathrm{II}} 250\right)$ transcription factor (Li et al. 2004), each stimulate the interaction of TAD2 with the pleckstrin homology (PH) region of p62 (Di Lello et al. 2006). Additionally, p53 competes with the $\alpha$ subunit of TFIIE for a common binding site in p62, and phosphorylation of Ser46 and Thr55 additively favors p53 binding (Di Lello et al. 2008). Phosphorylation of these residues may therefore govern transcriptional outcome by dynamically influencing whether $\mathrm{p} 62$ preferentially interacts with TFIIE or p53. Phosphorylation of p53 is also likely to regulate interaction with other transcription modulators such as PC4 (Rajagopalan et al. 2009) or SMAR1 (Pavithra et al. 2009), but much work is needed to characterize fully the influence of phosphorylation on these interactions.

\section{PHOSPHORYLATION OF SERINES 6 AND 9 - DEVELOPMENTAL AND CANCER-RELATED ROLES}

Serines 6 and 9 were originally identified as targets of the protein kinase CK1 family members, CK1 $\delta$ and CK1e (Knippschild et al. 1997; Higashimoto et al. 2000). These sites are 
modified after exposure to various genotoxic and nongenotoxic agents (Higashimoto et al. 2000; Saito et al. 2003), but it is unclear what functional role(s) these two modifications have in the DNA damage/stress response. Strikingly, they assume a critical role in the context of mesoderm development in Xenopus (Cordenonsi et al. 2007) (Fig. 5). p53 is required for efficient induction of mesoderm-specific gene expression and integrates signaling events downstream of transforming growth factor- $\beta$ (TGF- $\beta$ ) and fibroblast growth factor (FGF). Mechanistically, this integration necessitates p53 interacting with TGF$\beta$-activated Smad2 and is mediated through the phosphorylation of Ser6 and Ser9. p53 proteins with alanine residues substituted at these phosphorylation sites fail to interact with Smad2 and show impaired mesoderm-inducing ability in Xenopus embryos. Additionally, p53 expression restores the TGF- $\beta$ cytostatic program to human H1299 cells through increased p21 expression. Notably, however, S6A or S9A mutants cannot mediate TGF- $\beta$-dependent p21 expression or growth arrest but do fully retain the ability to transactivate expression of other p53-responsive

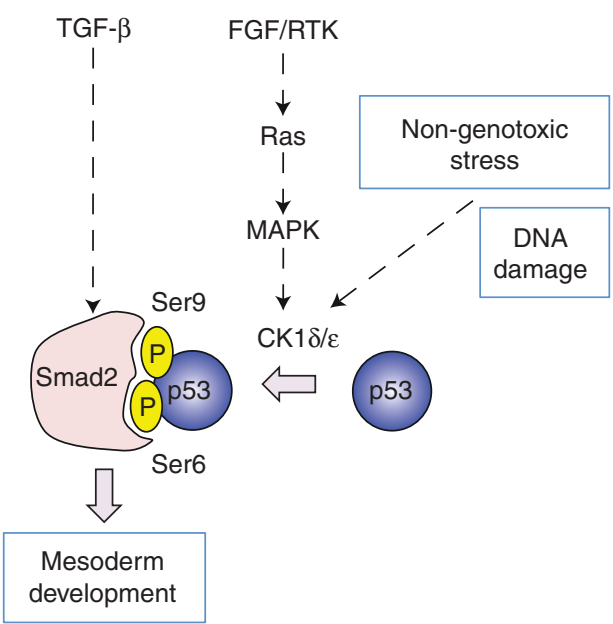

Figure 5. Phosphorylation and function of serines 6 and 9 in p53. Phosphorylation of Ser6 and Ser9 in p53 integrates TGF- $\beta$ - and FGF-signaling by promoting the interaction of p53 with Smad2. These residues are also modified in response to various genotoxic and nongenotoxic stresses, but their function in this context is not yet defined. genes such as MDM2 and BAX. These findings highlight a critical specificity in the function of these modifications. The protein kinases CK1 $\delta$ and CK1 $1 \varepsilon$ are important for the phosphorylation of p53 in response to FGF signaling, but the mechanism by which the Ras/MAPK pathway promotes CK1-mediated phosphorylation of p53 is not apparent.

The phosphorylation of Ser6 and Ser9 may also be important in tumorigenesis and metastatic progression promoted by TGF- $\beta$, activated Ras, and mutant p53 (Adorno et al. 2009). According to this model, Ras signaling promotes the phosphorylation of mutant p53 and leads to the formation of a mutant p53/Smad complex that can sequester p63, a p53 family member, thereby inhibiting its ability to activate expression of key antimetastasis genes. The model explains why TGF- $\beta$, which normally is cytostatic, has prometastatic properties in tumor cells expressing activated Ras and mutant p53. It additionally predicts that antitumor drugs, by inducing the phosphorylation of Ser6 and Ser9, may actually promote aggressive tumorigenesis; however, this idea remains to be tested.

\section{OTHER PHOSPHORYLATION EVENTS IN p53}

Owing to space constraints, the roles of other phosphorylation sites in p53 will not be discussed here, as they have been covered comprehensively in several reviews (Meek 1999; Appella and Anderson 2001; Bode and Dong 2004; Toledo and Wahl 2006; Olsson et al. 2007; Anderson and Appella 2009).

\section{CRITICAL ROLE OF ACETYLATION IN SELECTIVELY REGULATING p53 FUNCTION}

Many of the lysines targeted by ubiquitylation (and other modifications described later) are also acetylated. Importantly, ubiquitylation and acetylation (as well as neddylation and methylation) are mutually exclusive events with different outcomes for p53 regulation.

Seven carboxy-terminal lysine residues (K305, K370, K372, K373, K381, K382, and K386) and one DBD residue (K164) are acetylated by 
CBP (KAT3A)/p300 (KAT3B) (Gu and Roeder 1997; Sakaguchi et al. 1998; Liu et al. 1999; Wang et al. 2003; Tang et al. 2008), whereas K320 is acetylated by PCAF (KAT2B) (Sakaguchi et al. 1998; Liu et al. 1999). Acetylation of lysine residues is induced in response to various forms of genotoxic and nongenotoxic stress with the outcome that p53 is stabilized and activated, in part because the acetylated residues cannot be ubiquitylated by MDM2 (Sakaguchi et al. 1998; Ito et al. 2001; Li et al. 2002b). In addition to these residues, $\mathrm{K} 120$ is acetylated through the action of Tip60/hMOF, a MYST family HAT that is unrelated to p300/CBP or PCAF (Berns et al. 2004; Sykes et al. 2006; Tang et al. 2006). Interestingly, this site is a DNA contact residue within the DNA binding domain and is a recurrent target for mutation during tumor development. K120 acetylation is induced by DNA damage, and the modified p53 localizes preferentially to the promoters of key proapoptotic genes but not to those involved in cell cycle arrest. Consistent with these observations, a K120R mutant shows no effect on $p 21$ expression and retains its ability to arrest growth but fails to induce apoptosis (Sykes et al. 2006; Tang et al. 2006). These data suggest that K120 acetylation may have a decisive function in determining the outcome of p53 induction. Interestingly, K120-acetylated p53 is enriched at mitochondria where it is thought to have a transcription-independent function in regulating apoptosis by influencing the BAK/MCL-1 interaction (Sykes et al. 2009). Two additional acetylation sites, K319 and K357, were recently identified in p53 from SV40transformed monkey (COS-1) cells, but their significance is unknown (Joubel et al. 2009).

An understanding of the roles played by these acetylated residues has been approached using knockin mice in which lysine to arginine substitutions were made at the appropriate sites in p53. Mice substituted at six (Feng et al. 2005) or seven (Krummel et al. 2005) of these sites develop normally and show no increased susceptibility to cancer. Nevertheless, they do show subtle differences in the behavior of p53 in some cell types but not in others, suggesting that acetylation is context-dependent or other mechanisms can compensate for it. In a more recent study, Tang and colleagues (Tang et al. 2008) eliminated most of the major targets for acetylation (with the exception of K320) and determined the effects of these changes by expressing the mutant p53 proteins at physiological levels in cultured cells. Consistent with data from the knockin mice, substitution of individual lysines or groups of lysines had little or only subtle effects on p53-dependent expression of p21 (CDKN1A), BAX (BAX), PUMA (BBC3), and PIG3 (TP53I3). Strikingly, however, p53 in which all eight lysine residues were substituted $(8 \mathrm{KR})$ failed to induce p21 expression, yet was still fully competent to mediate expression of MDM2. These effects on transactivation were reflected in the loss of the ability of the $8 \mathrm{KR}$ mutant to mediate cell cycle arrest. The results suggest that: (a) acetylation plays a vital role in p53-mediated cell fate but does not influence the p53-MDM2 negative feedback regulatory loop; (b) the mechanisms of transactivation by p53 (as reflected by the requirement for posttranslational modification) differ depending on the promoter; and (c) there is a degree of redundancy between the various acetylation sites so that loss of one or more can be compensated by the remaining presence of others.

Mechanistically, the acetylated lysines are thought to participate in mediating "antirepression" (Tang et al. 2008; Kruse and Gu 2009). In this model, p53 situated on the promoters of responsive genes is inhibited from interacting with the transcriptional apparatus through complex formation with MDM2 and MDM4. Acetylation of p53 inhibits its interaction with MDM2 and MDM4. Moreover, unlike wild-type p53, the interaction of the $8 \mathrm{KR}$ mutant p53 with MDM2 and MDM4 on cellular promoters such as p21 or PIG3 cannot be competitively disrupted by increased expression of the HATs CBP or Tip60. These findings suggest a fundamental role for acetylation that may have been missed in the two existing lysine substitution mouse models (Feng et al. 2005; Krummel et al. 2005) owing to the fact that not all of the acetylation sites had been identified when these animals were generated. 
p53 Posttranslational Modifications

Thus, the question remains whether acetylation is truly indispensable for $\mathrm{p} 53$ function until it is resolved with experiments in mice expressing a p53 substitution mutant equivalent to the human 8KR mutant.

\section{OTHER MODIFICATIONS ON LYSINE RESIDUES}

p53 undergoes several other modifications that occur on lysine residues, including monoubiquitylation ( $\mathrm{Li}$ et al. 2003; Nie et al. 2007; Carter and Vousden 2008), conjugation of ubiquitin chains through lysine 63 (K63) of ubiquitin (Laine et al. 2006), sumoylation by SUMO-1 and SUMO-2/3 (Gostissa et al. 1999; Rodriguez et al. 1999; Kahyo et al. 2001; Schmidt and Müller 2002; Weger et al. 2005; Bischof et al. 2006), and neddylation (NEDD8) (Xirodimas et al. 2004; Abida et al. 2007; Carter and Vousden 2008). These have recently been discussed in detail elsewhere (Anderson and Appella 2009; Carter and Vousden 2009) and will not be developed further here.

Methylations of lysine and arginine were also recently established as reversible mechanisms that regulate p53 function (reviewed in Scoumanne and Chen 2008). In short, methylation occurs at carboxy-terminal residues K370, K372, and K382 (Fig. 1) (which are also targets for ubiquitylation and acetylation) and can enhance (Huang et al. 2007; Ivanov et al. 2007; Kurash et al. 2008) or suppress (Shi et al. 2007) p53 function depending on the site modified. Lysine methylation occurs in response to DNA damage (Huang et al. 2006; Ivanov et al. 2007; Kurash et al. 2008) and can facilitate (Ivanov et al. 2007; Kurash et al. 2008) or even inhibit (Huang et al. 2006) subsequent acetylation of other residues, a finding that underscores the interactive nature of PTMs in p53. Recently, Jansson et al. reported that three arginine residues in the p53 oligomerization domain (TET), R333, R335, and R337, are symmetrically dimethylated by PRMT5, a Class II methyltransferase (Jansson et al. 2008). These modifications add a significant level of complexity and interplay with other PTMs.

\section{OTHER MODIFICATIONS}

Modifications such as the addition of $O$-linked $N$-acetylglucosamine, ADP-ribosylation, prolyl isomerization, and oxidation of methionine have been reported to regulate p53 function. However, they are less well characterized, and their in vivo significance is poorly understood at present (Kruse and Gu 2008; Kruse and $\mathrm{Gu} 2009)$.

\section{BACK TO THE FUTURE-PTM REVERSAL}

All p53 PTMs are potentially reversible, and cellular enzymes have been identified that can reverse several of the PTMs discussed previously. Although these enzymes are less well studied than the transferases and ligases that act on p53, at least four protein phosphatases capable of dephosphorylating specific p53 sites in vitro have been identified (Fig. 1). Likewise, several deacetylases (HDACs) and the deubiquitinating enzyme HAUSP were shown to use p53 as a substrate and, through knockout or knock-down experiments, to affect cellular responses to DNA damage and other stresses (reviewed in Bode and Dong 2004; Brooks and Gu 2006). Also, one demethylase, KDM1, which demethylates Lys370, thus preventing binding of the p53 coactivator 53BP1, has been reported to date (Huang et al. 2007).

PTM-removal enzymes may play important roles in the recovery from stress. They may also make significant contributions toward setting the threshold for $\mathrm{p} 53$ activation, thereby preventing inappropriate p53 activation. Moreover, given that some modifications are mutually exclusive, de-modifying enzymes may be required to permit modification status to change, particularly in the context of chromatin-bound p53, where it is actively carrying out its function. For example, methylation of p53 at K372 by KMT5 prevents methylation of K370 by KMT3C by blocking the interaction of KMT3C with p53. The level of methylated K372 increases very rapidly in response to DNA damage (Huang et al. 2006); therefore, methylation of K370 by KMT3C, which represses p53-mediated transcriptional activation, could require removal of 
the K372 methyl group to restore p53 activity to its basal level after DNA damage repair. Additionally, bearing these aspects in mind, the demodifying enzymes may influence tumor development and consequently may deserve equal consideration with modifying enzymes as potential targets for novel antitumor drugs. We highlight two examples that underpin these important concepts.

Phosphatases are the best studied of the enzymes that remove PTMs from p53 (Fig. 1). Dephosphorylation of $\mathrm{p} 53$ by protein phosphatase 1 (PP1) and PP2A was recently summarized (Anderson and Appella 2009). PPM1D (WIP1), a relatively newly discovered member of the PP2C subfamily, is the product of a p53responsive gene that not only partially inactivates the p38 and JNK MAP kinases (Fiscella et al. 1997; Takekawa et al. 2000) but also attenuates the $\mathrm{p} 53$ and DNA response pathways by dephosphorylating p53-Ser15, MDM2Ser395 (also an ATM target) (Lu et al. 2007), and PIKK kinases, including ATM itself (Yamaguchi et al. 2007; reviewed in Lu et al. 2008). Analyses using PPM1D knockout mice confirm this role and provide evidence that PPM1D also functions in setting the threshold for p53 activation (Shreeram et al. 2006a; Shreeram et al. 2006b). Additionally, PPM1D is overexpressed in 15-18 percent of primary human breast cancers (and several others) and thus functions as an oncogene, whereas inhibition of PPM1D activity or deletion of the gene protects mice from tumors in several model systems (Bulavin et al. 2002; Li et al. 2002a). This demodifying enzyme, when overexpressed, is highly likely to contribute to the development of disease and thus may be a potential drug target.

Four classes of enzymes that reverse protein acetylation have been described based on their homology with yeast HDACs (Yang and Seto 2008). Various groups (Ito et al. 2002; Glozak et al. 2005) have shown that HDAC1, a member of the class I sub-family can deacetylate most, if not all, acetylated p53 residues in vitro and in cultured cells. Interestingly, HDAC1 recruitment is mediated by MDM2 and promotes p53 degradation (Ito et al. 2002). This activity is not displayed by other class I family members including HDAC-2 and -3 , nor by the class II members HDAC-4 and -5 .

p53 can also be deacetylated by the class III HDACs, which are homologs of yeast Sir2 and known as sirtuins in mammals. Sirtuins require $\mathrm{NAD}+$ as a cofactor and are not inhibited by tricostatin A (TSA). Three groups of researchers showed that SIRT1, the closest homolog to Sir2, interacted with p53 in the nucleus and specifically deacetylated K382 of p53 (Smith 2002). SIRT1-mediated deacetylation prevented p53-dependent transactivation of CDKN1A ( $\mathrm{p} 21^{\text {Wafl }}$ gene), and its activity, which is expressed predominantly in the developing nervous system, can be modulated positively or negatively by a number of cofactors, including necdin, which recruits SIRT1 to the transactivation domain of p53 (Hasegawa and Yoshikawa 2008). Similar to HDAC1, it is likely that SIRT1 can deacetylate all of the major p53 acetylation sites (Brooks and Gu 2009), but supporting data have not yet been published. Of particular interest, SirT1 and SirT2 were identified as the targets of Tenovin6 , a novel and highly potent small-molecule activator of the p53 pathway that not only shows striking cytotoxicity in cultured cells but also inhibits the growth of highly aggressive melanoma xenograft tumors (Lain et al. 2008). These data strongly support the principle that enormous therapeutic opportunities lie in manipulating the activity of key p53-targeted demodifying enzymes.

\section{CONCLUSIONS AND PERSPECTIVES}

Never in the field of molecular oncology have so many sites of posttranslational modification in one protein (p53) been modified by so many different enzymes! How do we make sense of such an eye-watering number of PTMs within a single protein?

An idea emerging from recent studies is that emphasis on individual sites of modification and efforts to assign function in a cellular context may be in many cases inappropriate. Although this approach has occasionally been successful, the individual modifications so far 
tested in the context of knockin mice have not revealed the striking phenotypes predicted by biochemistry and cultured cell analyses, and the subtle effects observed are often tissue- or cell-type-specific (Hoogervorst et al. 2005; Toledo and Wahl 2006; Armata et al. 2007; Iwakuma and Lozano 2007). This concept is pitched against the assumption that there has been strong selective pressure during evolution to put these modifications in place.

So how do we rationalize this concept? Three potentially interesting themes emerge. First, when considering the structural and biophysical data that have been published recently on the amino-terminal phosphorylation sites, it seems that contact with transcriptional proteins improves as the number of sites phoshorylated increases. Could this finding imply that phosphorylation works best in a collective sense? In other words, that physiological, multisite modification is the more effective means of switching on a pathway? Considering that Ser15 phosphorylation seems to act as a nucleation event that stimulates modifications of other sites (phosphorylation and acetylation), finetuning the outcome of p53 activation would then depend on the extent to which individual signaling pathways targeting individual sites contribute to this whole.

A second emerging theme is the essential yet flexible nature of acetylation. As discussed previously, Wei Gu's laboratory (Tang et al. 2008) showed that p53 that cannot be acetylated is essentially inactive other than as a stimulator of its own degradation apparatus. Having so many acetylation sites could therefore be a safeguard that p53 needs to maintain its function. Nevertheless, we still do not know how acetylation of different residues governs precise protein-protein interactions or the molecular basis for their contribution to promoter selectivity.

A third emerging theme is the interdependence and the sequential nature of these modifications. A principal purpose of aminoterminal phosphorylation is to recruit factors to stimulate transcription; thus, there is a clear integration of multiple sequential events in which phosphorylation-dependent recruitment of HATs not only opens up the chromatin but contributes further to the activation of p53. Moreover, the "switch" is not a simple one. For example, alone, phosphorylation at the amino terminus of p53 disrupts its interaction with the MDM2 amino-terminal pocket, but there are still other points of contact that are relieved by subsequent acetylation of the carboxyl terminus. Notably, these same modifications simultaneously activate transcription. It is very difficult to see how such complexity could be dissected in a knockin mouse with one or a few substitutions!

Our progress in the study of p53 PTMs has raised a number of key questions. Are any p53 PTMs (e.g., acetylation, [Tang et al. 2008]) truly essential? Are PTMs truly connected with tumor suppression? Data from phosphorylation-site-substituted mice show an influence on tumor susceptibility, albeit subtly and in tissue/cell-specific contexts (Bruins et al. 2004; MacPherson et al. 2004; Sluss et al. 2004; Hoogervorst et al. 2005; Chao et al. 2006; Armata et al. 2007). How susceptible to tumor development would a mouse be if Thr21 (equivalent to human Thr18), or indeed all of the major amino-terminal phosphorylation sites involved in regulating its interaction with MDM2 and p300, were eliminated? And if PTMs do not play a key role in tumor suppression, then is it possible that they regulate one or more of the newly discovered homeostatic functions now attributed to p53? The recent work from Piccolo's group on the interaction with Smad proteins tends to support this idea (Cordenonsi et al. 2007). Moreover, given that p53 represses the expression of many important genes, what role do modifications play in p53mediated repression? And if, as many studies suggest, phosphorylation and acetylation are involved in selectively influencing p53-mediated transcription, what are the mechanisms?

p53 phosphorylation is not required following its induction through the ARF pathway or in response to synthetic inducers such as Nutlins. So how is this possible, and why then do these modifications occur? Why has evolution selected not only for their presence but for such a wide range of possible modifications and 
combinations of events? Certainly, if one looks at the very exquisite structural and biochemical analyses of phosphorylation site function (discussed previously), it is breathtaking that the paradigms based on these analyses do not hold true (so far) in animal models. How do we rationalize this?

We are surely at a very stimulating and exciting stage in the study of p53 modifications. Although 30 years of effort and progress by many laboratories (much of which could not be included in this article) has enhanced our understanding of how these events regulate p53 function, we are still at an early stage. In particular, the recent demonstration of the genetic separation of the DNA damage response and tumor suppression (Efeyan and Serrano 2007) together with the recognition that p53 most likely evolved, at least in mammals, to perform regulatory roles in development, metabolism, and other normal cellular processes (Aranda-Anzaldo and Dent 2007; Danilova et al. 2008; Tedeschi and Di Giovanni 2009; Vousden and Prives 2009) invites the study of PTMs in these processes. The questions raised by these findings may dominate our attention for some time to come; nevertheless, the steady progress achieved in understanding the roles of p53 PTMs suggests that one may justifiably be optimistic that more interesting and telling answers will emerge over the next few years.

\section{REFERENCES}

Abida WM, Nikolaev A, Zhao W, Zhang W, Gu W. 2007. FBXO11 promotes the neddylation of p53 and inhibits its transcriptional activity. J Biol Chem 282: 1797-1804.

Adorno M, Cordenonsi M, Montagner M, Dupont S, Wong C, Hann B, Solari A, Bobisse S, Rondina MB, Guzzardo V et al. 2009. A Mutant-p53/Smad complex opposes p63 to empower TGF $\beta$-induced metastasis. Cell 137: 87-98.

Allton K, Jain AK, Herz H-M, Tsai W-W, Jung SY, Qin J, Bergmann A, Johnson RL, Barton MC. 2009. Trim24 targets endogenous p53 for degradation. Proc Natl Acad Sci 106: 11612-11616.

Anderson CW, Appella E. 2009. Signaling to the p53 tumor suppressor through pathways activated by genotoxic and non-genotoxic stresses. In Handbook of Cell Signaling (eds. RA Bradshaw, EA Dennis), Chapter 264, p. 21852203, Elsevier, Amsterdam.
Appella E, Anderson CW. 2001. Post-translational modifications and activation of p53 by genotoxic stresses. Eur J Biochem 268: 2764-2772.

Aranda-Anzaldo A, Dent MAR. 2007. Reassessing the role of p53 in cancer and ageing from an evolutionary perspective. Mech Ageing Dev 128: 293-302.

Armata HL, Garlick DS, Sluss HK. 2007. The ataxia telangiectasia-mutated target site Ser18 is required for p53-mediated tumor suppression. Cancer Res 67: 11696-11703.

Avantaggiati ML, Ogryzko V, Gardner K, Giordano A, Levine AS, Kelly K. 1997. Recruitment of p300/CBP in p53-dependent signal pathways. Cell 89: 1175-1184.

Berns K, Hijmans EM, Mullenders J, Brummelkamp TR, Velds A, Heimerikx M, Kerkhoven RM, Madiredjo M, Nijkamp W, Weigelt B et al. 2004. A large-scale RNAi screen in human cells identifies new components of the p53 pathway. Nature 428: 431-437.

Bischof O, Schwamborn K, Martin N, Werner A, Sustmann C, Grosschedl R, Dejean A. 2006. The E3 SUMO ligase PIASy is a regulator of cellular senescence and apoptosis. Mol Cell 22: 783-794.

Bode AM, Dong Z. 2004. Post-translational modification of p53 in tumorigenesis. Nat Rev Cancer 4: 793-805.

Böttger V, Böttger A, Garcia-Echeverria C, Ramos YFM, van der Eb AJ, Jochemsen AG, Lane DP. 1999. Comparative study of the p53-mdm2 and p53-MDMX interfaces. Oncogene 18: 189-199.

Brooks CL, Gu W. 2006. p53 Ubiquitination: Mdm2 and beyond. Mol Cell 21: 307-315.

Brooks CL, Gu W. 2009. How does SIRT1 affect metabolism, senescence and cancer? Nat Rev Cancer 9: 123-128.

Bruins W, Zwart E, Attardi LD, Iwakuma T, Hoogervorst EM, Beems RB, Miranda B, van Oostrom CTM, van den Berg J, van den Aardweg GJ et al. 2004. Increased sensitivity to UV radiation in mice with a p53 point mutation at Ser389. Mol Cell Biol 24: 8884-8894.

Bulavin DV, Demidov ON, Saito S, Kauraniemi P, Phillips C, Amundson SA, Ambrosino C, Sauter G, Nebreda AR, Anderson CW et al. 2002. Amplification of PPM1D in human tumors abrogates p53 tumor-suppressor activity. Nat Genet 31: 210-215.

Bulavin DV, Saito S, Hollander MC, Sakaguchi K, Anderson CW, Appella E, Fornace AJJr. 1999. Phosphorylation of human $\mathrm{p} 53$ by $\mathrm{p} 38$ kinase coordinates $\mathrm{N}$-terminal phosphorylation and apoptosis in response to UV radiation. EMBO J 18: 6845-6854.

Candau R, Scolnick DM, Darpino P, Ying CY, Halazonetis TD, Berger SL. 1997. Two tandem and independent subactivation domains in the amino terminus of $\mathrm{p} 53$ require the adaptor complex for activity. Oncogene 15: 807-816.

Carter S, Vousden KH. 2008. p53-Ubl fusions as models of ubiquitination, sumoylation and neddylation of p53. Cell Cycle 7: 2519-2528.

Carter S, Vousden KH. 2009. Modifications to p53: Competing for the lysines. Curr Op Genet Dev 19: 1-7.

Chang J, Kim D-H, Lee SW, Choi KY, Sung YC. 1995. Transactivation ability of p53 transcriptional activation domain is directly related to the binding affinity to TATA-binding protein. J Biol Chem 270: 25014-25019. 
Chao C, Herr D, Chun J, Xu Y. 2006. Ser18 and 23 phosphorylation is required for p53-dependent apoptosis and tumor suppression. EMBO J 25: 2615-2622.

Chehab NH, Malikzay A, Stavridi ES, Halazonetis TD. 1999. Phosphorylation of Ser-20 mediates stabilization of human p53 in response to DNA damage. Proc Natl Acad Sci 96: 13777-13782.

Cordenonsi M, Montagner M, Adorno M, Zacchigna L, Martello G, Mamidi A, Soligo S, Dupont S, Piccolo S. 2007. Integration of TGF- $\beta$ and Ras/MAPK signaling through p53 phosphorylation. Science 315: 840-843.

Craig AL, Blaydes JP, Burch LR, Thompson AM, Hupp TR. 1999. Dephosphorylation of p53 at Ser20 after cellular exposure to low levels of non-ionizing radiation. Oncogene 18: 6305-6312.

D’Orazi G, Cecchinelli B, Bruno T, Manni I, Higashimoto Y, Saito S, Gostissa M, Coen S, Marchetti A, Del Sal G et al. 2002. Homeodomain-interacting protein kinase-2 phosphorylates p53 at Ser 46 and mediates apoptosis. Nat Cell Biol 4: 11-19.

Danilova N, Sakamoto KM, Lin S. 2008. p53 family in development. Mech Dev 125: 919-931.

Dauth I, Krüger J, Hofmann TG. 2007. Homeodomaininteracting protein kinase 2 is the ionizing radiationactivated p53 serine 46 kinase and is regulated by ATM Cancer Res 67: 2274-2279.

de Stanchina E, McCurrach ME, Zindy F, Shieh SY, Ferbeyre G, Samuelson AV, Prives C, Roussel MF, Sherr CJ, Lowe SW. 1998. E1A signaling to p53 involves the p19(ARF) tumor suppressor. Genes Dev 12: 2434-2442.

Di Lello P, Jenkins LMM, Jones TN, Nguyen BD, Hara T, Yamaguchi H, Dikeakos JD, Appella E, Legault P, Omichinski JG. 2006. Structure of the Tfb1/p53 complex: Insights into the interaction between the p62/ $\mathrm{Tfb} 1$ subunit of TFIIH and the activation domain of p53. Mol Cell 22: 731-740.

Di Lello P, Miller Jenkins LM, Mas C, Langlois C, Malitskaya E, Fradet-Turcotte A, Archambault J, Legault P, Omichinski JG. 2008. p53 and TFIIE $\alpha$ share a common binding site on the Tfb1/p62 subunit of TFIIH. Proc Natl Acad Sci 105: 106-111.

Dornan D, Hupp TR. 2001. Inhibition of p53-dependent transcription by BOX-I phospho-peptide mimetics that bind to p300. EMBO Rep 2: 139-144.

Dornan D, Shimizu H, Burch L, Smith AJ, Hupp TR. 2003. The proline repeat domain of $\mathrm{p} 53$ binds directly to the transcriptional coactivator p300 and allosterically controls DNA-dependent acetylation of p53. Mol Cell Biol 23: 8846-8861.

Dumaz N, Meek DW. 1999. Serine15 phosphorylation stimulates p53 transactivation but does not directly influence interaction with HDM2. EMBO J 18: $7002-7010$.

Dumaz N, Milne DM, Meek DW. 1999. Protein kinase CK1 is a p53-threonine 18 kinase which requires prior phosphorylation of serine 15. FEBS Lett 463: 312-316.

Dumaz N, Milne DM, Jardine LJ, Meek DW. 2001. Critical roles for the serine 20, but not the serine 15, phosphorylation site and for the polyproline domain in regulating p53 turnover. Biochem J 359: 459-464.
Efeyan A, Serrano M. 2007. p53: Guardian of the genome and policeman of the oncogenes. Cell Cycle 6: 1006-1010.

Espinosa JM, Emerson BM. 2001. Transcriptional regulation by $\mathrm{p} 53$ through intrinsic DNA/chromatin binding and site-directed cofactor recruitment. $\mathrm{Mol}$ Cell 8: 57-69.

Feng H, Jenkins LM, Durell SR, Hayashi R, Mazur SJ, Cherry S, Tropea JE, Miller M, Wlodawer A, Appella E et al. 2009. Structural basis for p300 Taz2-p53 TAD1 binding and modulation by phosphorylation. Structure 17: 202-210.

Feng L, Lin T, Uranishi H, Gu W, Xu Y. 2005. Functional analysis of the roles of posttranslational modifications at the p53 C terminus in regulating p53 stability and activity. Mol Cell Biol 25: 5389-5395.

Ferreon JC, Lee CW, Arai M, Martinez-Yamout MA, Dyson HJ, Wright PE. 2009. Cooperative regulation of p53 by modulation of ternary complex formation with CBP/ p300 and HDM2. Proc Natl Acad Sci 106: 6591-6596.

Finlan L, Hupp TR. 2004. The N-terminal interferonbinding domain (IBiD) homology domain of p300 binds to peptides with homology to the p53 transactivation domain. J Biol Chem 279: 49395-49405.

Fiscella M, Zhang H, Fan S, Sakaguchi K, Shen S, Mercer WE, Vande Woude GF, O'Connor PM, Appella E. 1997. Wip1, a novel human protein phosphatase that is induced in response to ionizing radiation in a $\mathrm{p} 53$ dependent manner. Proc Natl Acad Sci 94: 6048-6053.

Glozak MA, Sengupta N, Zhang X, Seto E. 2005. Acetylation and deacetylation of non-histone proteins. Gene 363: $15-23$.

Gostissa M, Hengstermann A, Fogal V, Sandy P, Schwarz SE, Scheffner M, Del Sal G. 1999. Activation of p53 by conjugation to the ubiquitin-like protein SUMO-1. EMBO J 18: $6462-6471$.

Grossman SR, Deato ME, Brignone C, Chan HM, Kung AL, Tagami H, Nakatani Y, Livingston DM. 2003. Polyubiquitination of p53 by a ubiquitin ligase activity of p300. Science 300: 342-344.

Grossman SR, Perez M, Kung AL, Joseph M, Mansur C, Xiao Z-X, Kumar S, Howley PM, Livingston DM. 1998. p300 MDM2 complexes participate in MDM2-mediated p53 degradation. Mol Cell 2: 405-415.

Gu W, Roeder RG. 1997. Activation of p53 sequence-specific DNA binding by acetylation of the p53 C-terminal domain. Cell 90: 595-606.

Gu W, Shi X-L, Roeder RG. 1997. Synergistic activation of transcription by CBP and p53. Nature 387: 819-823.

Hasegawa K, Yoshikawa K. 2008. Necdin regulates p53 acetylation via Sirtuin1 to modulate DNA damage response in cortical neurons. J Neurosci 28: 8772-8784.

Higashimoto Y, Saito S, Tong X-H, Hong A, Sakaguchi K, Appella E, Anderson CW. 2000. Human p53 is phosphorylated on serines 6 and 9 in response to DNA damage-inducing agents. J Biol Chem 275: 23199-23203.

Hofmann TG, Möller A, Sirma H, Zentgraf H, Taya Y, Dröge W, Will H, Schmitz ML. 2002. Regulation of p53 activity by its interaction with homeodomain-interacting protein kinase-2. Nat Cell Biol 4: 1-10.

Hoogervorst EM, Bruins W, Zwart E, van Oostrom CTM, van den Aardweg GJ, Beems RB, van den Berg J, 
D.W. Meek and C.W. Anderson

Jacks T, van Steeg H, de Vries A. 2005. Lack of p53 Ser389 phosphorylation predisposes mice to develop 2acetylaminofluorene-induced bladder tumors but not ionizing radiation-induced lymphomas. Cancer Res 65: 3610-3616.

Huang J, Perez-Burgos L, Placek BJ, Sengupta R, Richter M, Dorsey JA, Kubicek S, Opravil S, Jenuwein T, Berger SL. 2006. Repression of p53 activity by Smyd2-mediated methylation. Nature 444: 629-632.

Huang J, Sengupta R, Espejo AB, Lee MG, Dorsey JA, Richter M, Opravil S, Shiekhattar R, Bedford MT, Jenuwein T et al. 2007. p53 is regulated by the lysine demethylase LSD1. Nature 449: 105-108.

Hupp TR, Meek DW, Midgley CA, Lane DP. 1992. Regulation of the specific DNA binding function of p53. Cell 71: 875-886.

Ito A, Kawaguchi Y, Lai C-H, Kovacs JJ, Higashimoto Y, Appella E, Yao T-P. 2002. MDM2-HDAC1-mediated deacetylation of p53 is required for its degradation. EMBO J 21: 6236-6245.

Ito A, Lai C-H, Zhao X, Saito S, Hamilton MH, Appella E, Yao T-P. 2001. p300/CBP-mediated p53 acetylation is commonly induced by p53-activating agents and inhibited by MDM2. EMBO J 20: 1331-1340.

Ivanov GS, Ivanova T, Kurash J, Ivanov A, Chuikov S, Gizatullin F, Herrera-Medina EM, Rauscher F3rd, Reinberg D, Barlev NA. 2007. Methylation-acetylation interplay activates p53 in response to DNA damage. Mol Cell Biol 27: 6756-6769.

Iwakuma T, Lozano G. 2007. Crippling p53 activities via knock-in mutations in mouse models. Oncogene 26: 2177-2184.

Jansson M, Durant ST, Cho E-C, Sheahan S, Edelmann M, Kessler B, La Thangue NB. 2008. Arginine methylation regulates the p53 response. Nat Cell Biol 10: 1431-1439.

Jenkins JR, Rudge K, Redmond S, Wade-Evans A. 1984. Cloning and expression analysis of full length mouse cDNA sequences encoding the transformation associated protein p53. Nucleic Acids Res 12: 5609-5626.

Jenkins LM, Yamaguchi H, Hayashi R, Cherry S, Tropea JE, Miller M, Wlodawer A, Appella E, Mazur SJ. 2009. Two distinct motifs within the p53 transactivation domain bind to the Taz2 domain of p300 and are differentially affected by phosphorylation. Biochemistry 48: 1244-1255.

Jones RG, Plas DR, Kubek S, Buzzai M, Mu J, Xu Y, Birnbaum MJ, Thompson CB. 2005. AMP-activated protein kinase induces a p53-dependent metabolic checkpoint. Mol Cell 18: 283-293.

Jones SN, Roe AE, Donehower LA, Bradley A. 1995. Rescue of embryonic lethality in Mdm2-deficient mice by absence of p53. Nature 378: 206-208.

Joubel A, Chalkley RJ, Medzihradszky KF, Hondermarck H, Burlingame AL. 2009. Identification of new p53 acetylation sites in COS-1 cells. Mol Cell Proteomics 8: 1167-1173.

Kahyo T, Nishida T, Yasuda H. 2001. Involvement of PIAS1 in the sumoylation of tumor suppressor p53. Mol Cell 8: 713-718.

Kastan MB, Onyekwere O, Sidransky D, Vogelstein B, Craig RW. 1991. Participation of p53 protein in the cellular response to DNA damage. Cancer Res 51: 6304-6311.
Knippschild U, Milne DM, Campbell LE, DeMaggio AJ, Christenson E, Hoekstra MF, Meek DW. 1997. p53 is phosphorylated in vitro and in vivo by the $\delta$ and $\varepsilon$ isoforms of casein kinase 1 and enhances the level of casein kinase $1 \delta$ in response to topoisomerase-directed drugs. Oncogene 15: 1727-1736.

Krummel KA, Lee CJ, Toledo F, Wahl GM. 2005. The C-terminal lysines fine-tune P53 stress responses in a mouse model but are not required for stability control or transactivation. Proc Natl Acad Sci 102: 10188 10193.

Kruse JP, Gu W. 2008. SnapShot: p53 posttranslational modifications. Cell 133: e931.

Kruse JP, Gu W. 2009. Modes of p53 regulation. Cell 137: 609-622.

Kurash JK, Lei H, Shen Q, Marston WL, Granda BW, Fan H, Wall D, Li E, Gaudet F. 2008. Methylation of p53 by Set7/9 mediates p53 acetylation and activity in vivo. Mol Cell 29: 392-400.

Lain S, Hollick JJ, Campbell J, Staples OD, Higgins M, Aoubala M, McCarthy A, Appleyard V, Murray KE, Baker L et al. 2008. Discovery, in vivo activity, and mechanism of action of a small-molecule p53 activator. Cancer Cell 13: 454-463.

Laine A, Topisirovic I, Zhai D, Reed JC, Borden KLB, Ronai Z. 2006. Regulation of p53 localization and activity by Ubc13. Mol Cell Biol 26: 8901-8913.

Lambert PF, Kashanchi F, Radonovich MF, Shiekhattar R, Brady JN. 1998. Phosphorylation of p53 serine 15 increases interaction with CBP. J Biol Chem 273: 33048 33053.

Lane DP. 1992. Cancer. p53, guardian of the genome. Nature 358: $15-16$.

Lee CW, Arai M, Martinez-Yamout MA, Dyson HJ, Wright PE. 2009a. Mapping the interactions of the p53 transactivation domain with the KIX domain of CBP. Biochemistry 48: 2115-2124.

Lee E-W, Lee M-S, Camus S, Ghim J, Yang M-R, Oh W, Ha N-C, Lane DP, Song J. 2009b. Differential regulation of p53 and p21 by MKRN1 E3 ligase controls cell cycle arrest and apoptosis. EMBO J 28: 2100-2113.

Lees-Miller SP, Sakaguchi K, Ullrich SJ, Appella E, Anderson CW. 1992. Human DNA-activated protein kinase phosphorylates serines 15 and 37 in the amino-terminal transactivation domain of human p53. Mol Cell Biol 12: 5041-5049.

Li H-H, Li AG, Sheppard HM, Liu X. 2004. Phosphorylation on Thr- 55 by TAF1 mediates degradation of $\mathrm{p} 53$ : A role for TAF1 in cell G1 progression. Mol Cell 13: 867-878.

Li J, Yang Y, Peng Y, Austin RJ, van Eyndhoven WG, Nguyen KCQ, Gabriele T, McCurrach ME, Marks JR, Hoey Tet al. 2002a. Oncogenic properties of PPM1D located within a breast cancer amplification epicenter at 17q23. Nat Genet 31: 133-134.

Li M, Brooks CL, Wu-Baer F, Chen D, Baer R, Gu W. 2003. Mono- versus polyubiquitination: Differential control of p53 fate by Mdm2. Science 302: 1972-1975.

Li M, Luo J, Brooks CL, Gu W. 2002b. Acetylation of p53 inhibits its ubiquitination by Mdm2. J Biol Chem 277: 50607-50611. 
Lill NL, Grossman SR, Ginsberg D, DeCaprio J, Livingston DM. 1997. Binding and modulation of p53 by p300/ CBP coactivators. Nature 387: 823-827.

Liu L, Scolnick DM, Trievel RC, Zhang HB, Marmorstein R, Halazonetis TD, Berger SL. 1999. p53 sites acetylated in vitro by $\mathrm{PCAF}$ and $\mathrm{p} 300$ are acetylated in vivo in response to DNA damage. Mol Cell Biol 19: 1202-1209.

Livengood JA, Scoggin KES, Van Orden K, McBryant SJ, Edayathumangalam RS, Laybourn PJ, Nyborg JK. 2002. p53 Transcriptional activity is mediated through the SRC1-interacting domain of $\mathrm{CBP} / \mathrm{p} 300$. J Biol Chem 277: 9054-9061.

Lu X, Ma O, Nguyen T-A, Jones SN, Oren M, Donehower LA. 2007. The Wip1 phosphatase acts as a gatekeeper in the p53-Mdm2 autoregulatory loop. Cancer Cell 12: $342-354$.

Lu X, Nguyen TA, Moon SH, Darlington Y, Sommer M, Donehower LA. 2008. The type 2C phosphatase Wip1: An oncogenic regulator of tumor suppressor and DNA damage response pathways. Cancer Metastasis Rev 27: $123-135$.

MacPherson D, Kim J, Kim T, Rhee BK, van Oostrom CT, DiTullio RAJr, Venere M, Halazonetis TD, Bronson R, De Vries A et al. 2004. Defective apoptosis and B-cell lymphomas in mice with p53 point mutation at Ser 23 . EMBO J 23: 3689-3699.

Marine J-CW, Dyer MA, Jochemsen AG. 2007. MDMX: From bench to bedside. J Cell Sci 120: 371-378.

Meek DW. 1999. Mechanisms of switching on p53: A role for covalent modification? Oncogene 18: 7666-7675.

Meek DW. 2009. Tumour suppression by p53: A role for the DNA damage response? Nat Rev Cancer 9: 714-723.

Meek DW, Eckhart W. 1988. Phosphorylation of p53 in normal and simian virus 40-transformed NIH 3 T3 cells. Mol Cell Biol 8: 461-465.

Mellert H, Sykes SM, Murphy ME, McMahon SB. 2007. The ARF/oncogene pathway activates p53 acetylation within the DNA binding domain. Cell Cycle 6: 1304-1306.

Möller A, Sirma H, Hofmann TG, Rueffer S, Klimczak E, Dröge W, Will H, Schmitz ML. 2003. PML is required for homeodomain-interacting protein kinase 2 (HIPK2)mediated p53 phosphorylation and cell cycle arrest but is dispensable for the formation of HIPK domains. Cancer Res 63: 4310-4314.

Montes de Oca Luna R, Wagner DS, Lozano G. 1995. Rescue of early embryonic lethality in $m d m 2$-deficient mice by deletion of p53. Nature 378: 203-206.

Nie L, Sasaki M, Maki CG. 2007. Regulation of p53 nuclear export through sequential changes in conformation and ubiquitination. J Biol Chem 282: 14616-14625.

Olsson A, Manzl C, Strasser A, Villunger A. 2007. How important are post-translational modifications in p53 for selectivity in target-gene transcription and tumour suppression? Cell Death Differ 14: 1561-1575.

Pavithra L, Mukherjee S, Sreenath K, Kar S, Sakaguchi K, Roy S, Chattopadhyay S. 2009. SMAR1 forms a ternary complex with p53-MDM2 and negatively regulates p53-mediated transcription. J Mol Biol 388: 691-702.

Perfettini J-L, Castedo M, Nardacci R, Ciccosanti F, Boya P, Roumier T, Larochette N, Piacentini M, Kroemer G. 2005. Essential role of p53 phosphorylation by p38
MAPK in apoptosis induction by the HIV-1 envelope. J Exp Med 201: 279-289.

Polley S, Guha S, Roy NS, Kar S, Sakaguchi K, Chuman Y, Swaminathan V, Kundu T, Roy S. 2008. Differential recognition of phosphorylated transactivation domains of p53 by different p300 domains. J Mol Biol 376: 8-12.

Rajagopalan S, Andreeva A, Teufel DP, Freund SM, Fersht AR. 2009. Interaction between the transactivation domain of p53 and PC4 exemplifies acidic activation domains as ssDNA mimics. J Biol Chem 284: 21728-21737.

Ringshausen I, O'Shea CC, Finch AJ, Swigart LB, Evan GI. 2006. Mdm2 is critically and continuously required to suppress lethal p53 activity in vivo. Cancer Cell 10: 501-514.

Rodriguez MS, Desterro JMP, Lain S, Lane DP, Hay RT. 2000. Multiple C-terminal lysine residues target p53 for ubiquitin-proteasome-mediated degradation. Mol Cell Biol 20: 8458-8467.

Rodriguez MS, Desterro JMP, Lain S, Midgley CA, Lane DP, Hay RT. 1999. SUMO-1 modification activates the transcriptional response of p53. EMBO J 18: 6455-6461.

Saito S, Goodarzi AA, Higashimoto Y, Noda Y, Lees-Miller SP, Appella E, Anderson CW. 2002. ATM mediates phosphorylation at multiple p53 sites, including $\mathrm{Ser}^{46}$, in response to ionizing radiation. J Biol Chem 277: 12491-12494.

Saito S, Yamaguchi H, Higashimoto Y, Chao C, Xu Y, Fornace AJ Jr, Appella E, Anderson CW. 2003. Phosphorylation site interdependence of human p53 post-translational modifications in response to stress. J Biol Chem 278: 37536-37544.

Sakaguchi K, Herrera JE, Saito S, Miki T, Bustin M, Vassilev A, Anderson CW, Appella E. 1998. DNA damage activates p53 through a phosphorylation-acetylation cascade. Genes Dev 12: 2831-2841.

Sakaguchi K, Saito S, Higashimoto Y, Roy S, Anderson CW, Appella E. 2000. Damage-mediated phosphorylation of human p53 threonine 18 through a cascade mediated by a casein 1-like kinase. Effect on Mdm2 binding. J Biol Chem 275: 9278-9283.

Samad A, Anderson CW, Carroll RB. 1986. Mapping of phosphomonoester and apparent phosphodiester bonds of the oncogene product p53 from simian virus 40transformed 3T3 cells. Proc Natl Acad Sci 83: 897-901.

Schmidt D, Müller S. 2002. Members of the PIAS family act as SUMO ligases for c-Jun and p53 and repress p53 activity. Proc Natl Acad Sci 99: 2872-2877.

Schon O, Friedler A, Bycroft M, Freund SMV, Fersht A. 2002. Molecular mechanism of the interaction between MDM2 and p53. J Mol Biol 323: 491-501.

Scoumanne A, Chen X. 2008. Protein methylation: A new mechanism of p53 tumor suppressor regulation. Histol Histopathol 23: 1143-1149.

Shi X, Kachirskaia I, Yamaguchi H, West LE, Wen H, Wang EW, Dutta S, Appella E, Gozani O. 2007. Modulation of p53 function by SET8-mediated methylation at lysine 382. Mol Cell 27: 636-646.

Shieh SY, Ikeda M, Taya Y, Prives C. 1997. DNA damage-induced phosphorylation of p53 alleviates inhibition by MDM2. Cell $91: 325-334$. 
D.W. Meek and C.W. Anderson

Shreeram S, Demidov ON, Hee WK, Yamaguchi H, Onishi N, Kek C, Timofeev ON, Dudgeon C, Fornace AJ, Anderson CW et al. 2006a. Wipl phosphatase modulates ATM-dependent signaling pathways. Mol Cell 23: $757-764$.

Shreeram S, Hee WK, Demidov ON, Kek C, Yamaguchi H, Fornace AJJr, Anderson CW, Appella E, Bulavin DV 2006b. Regulation of ATM/p53-dependent suppression of myc-induced lymphomas by Wip1 phosphatase. J Exp Med 203: 2793-2799.

Sluss HK, Armata H, Gallant J, Jones SN. 2004. Phosphorylation of serine 18 regulates distinct p53 functions in mice. Mol Cell Biol 24: 976-984.

Smith JS. 2002. Human Sir2 and the 'silencing' of p53 activity. Trends Cell Biol 12: 404-406.

Sykes SM, Mellert HS, Holbert MA, Li K, Marmorstein R, Lane WS, McMahon SB. 2006. Acetylation of the p53 DNA-binding domain regulates apoptosis induction. Mol Cell 24: 841-851.

Sykes SM, Stanek TJ, Frank A, Murphy ME, McMahon SB. 2009. Acetylation of the DNA binding domain regulates transcription-independent apoptosis by p53. J Biol Chem 284: 20197-20205.

Taira N, Nihira K, Yamaguchi T, Miki Y, Yoshida K. 2007. DYRK2 is targeted to the nucleus and controls p53 via Ser46 phosphorylation in the apoptotic response to DNA damage. Mol Cell 25: 725-738.

Takekawa M, Adachi M, Nakahata A, Nakayama I, Itoh F, Tsukuda H, Taya Y, Imai K. 2000. p53-inducible Wip1 phosphatase mediates a negative feedback regulation of p38 MAPK-p53 signaling in response to UV radiation. EMBO J 19: 6517-6526.

Tang Y, Luo J, Zhang W, Gu W. 2006. Tip60-dependent acetylation of p53 modulates the decision between cellcycle arrest and apoptosis. Mol Cell 24: 827-839.

Tang Y, Zhao W, Chen Y, Zhao Y, Gu W. 2008. Acetylation is indispensable for p53 activation. Cell 133: 612-626.

Tedeschi A, Di Giovanni S. 2009. The non-apoptotic role of p53 in neuronal biology: Enlightening the dark side of the moon. EMBO Rep 10: 576-583.

Teufel DP, Bycroft M, Fersht AR. 2009. Regulation by phosphorylation of the relative affinities of the N-terminal transactivation domains of p53 for p300 domains and Mdm2. Oncogene 28: 2112-2118.

Teufel DP, Freund SM, Bycroft M, Fersht AR. 2007. Four domains of p300 each bind tightly to a sequence spanning both transactivation subdomains of p53. Proc Natl Acad Sci 104: 7009-7014.

Toledo F, Wahl GM. 2006. Regulating the p53 pathway: In vitro hypotheses, in vivo veritas. Nat Rev Cancer 6: 909-923.

Toledo F, Lee CJ, Krummel KA, Rodewald L-W, Liu C-W, Wahl GM. 2007. Mouse mutants reveal that putative protein interaction sites in the $\mathrm{p} 53$ proline-rich domain are dispensable for tumor suppression. Mol Cell Biol 27: $1425-1432$.

Unger T, Juven-Gershon T, Moallem E, Berger M, Vogt Sionov R, Lozano G, Oren M, Haupt Y. 1999. Critical role for Ser20 of human p53 in the negative regulation of p53 by Mdm2. EMBO J 18: 1805-1814.

Van Orden K, Giebler HA, Lemasson I, Gonzales M, Nyborg JK. 1999. Binding of p53 to the KIX domain of CREB binding protein. A potential link to human T-cell leukemia virus, type I-associated leukemogenesis. J Biol Chem 274: 26321-26328.

Vousden KH, Prives C. 2009. Blinded by the light: The growing complexity of p53. Cell 137: 413-431.

Wang Y-H, Tsay Y-G, Tan BC-M, Lo W-Y, Lee S-C. 2003. Identification and characterization of a novel p300mediated p53 acetylation site, lysine 305. J Biol Chem 278: $25568-25576$.

Weger S, Hammer E, Heilbronn R. 2005. Topors acts as a SUMO-1 E3 ligase for p53 in vitro and in vivo. FEBS Lett 579: 5007-5012.

Xirodimas DP, Saville MK, Bourdon J-C, Hay RT, Lane DP. 2004. Mdm2-mediated NEDD8 conjugation of p53 inhibits its transcriptional activity. Cell 118: 83-97.

Yamaguchi H, Durell SR, Chatterjee DK, Anderson CW, Appella E. 2007. The Wip1 phosphatase PPM1D dephosphorylates SQ/TQ motifs in checkpoint substrates phosphorylated by PI3K-like kinases. Biochemistry 46: 12594-12603.

Yang X-J, Seto E. 2008. The Rpd3/Hda1 family of lysine deacetylases: From bacteria and yeast to mice and men. Nat Rev Mol Cell Biol 9: 206-218. 


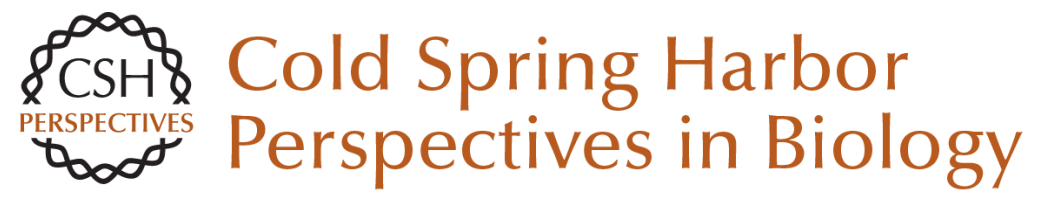

\section{Posttranslational Modification of p53: Cooperative Integrators of Function}

David W. Meek and Carl W. Anderson

Cold Spring Harb Perspect Biol 2009; doi: 10.1101/cshperspect.a000950 originally published online October 28, 2009

\section{Subject Collection The p53 Family}

The Origins and Evolution of the p53 Family of Genes

Vladimir A. Belyi, Prashanth Ak, Elke Markert, et al.

Mouse Models of p53 Functions

Guillermina Lozano

TP53 Mutations in Human Cancers: Origins, Consequences, and Clinical Use

Magali Olivier, Monica Hollstein and Pierre Hainaut

p53 Research: The Past Thirty Years and the Next Thirty Years

David Lane and Arnold Levine

Transcriptional Regulation by P53

Rachel Beckerman and Carol Prives

p53-based Cancer Therapy

David P. Lane, Chit Fang Cheok and Sonia Lain

Phylogeny and Function of the Invertebrate p53

Superfamily

Rachael Rutkowski, Kay Hofmann and Anton Gartner

Tied Up in Loops: Positive and Negative

Autoregulation of p53

Xin Lu
The Tumor Suppressor p53: From Structures to

Drug Discovery

Andreas C. Joerger and Alan R. Fersht

p53 Regulation of Metabolic Pathways

Eyal Gottlieb and Karen H. Vousden

The Regulation of the p53-mediated Stress

Response by MDM2 and MDM4

Mary Ellen Perry

Zebrafish Models of p53 Functions Narie Y. Storer and Leonard I. Zon

p63 and p73, the Ancestors of p53

V. Dötsch, F. Bernassola, D. Coutandin, et al.

Pathologies Associated with the p53 Response Andrei V. Gudkov and Elena A. Komarova

Single-nucleotide Polymorphisms in the p53

Signaling Pathway Lukasz F. Grochola, Jorge Zeron-Medina, Sophie Mériaux, et al.

Clinical Outcomes and Correlates of TP53

Mutations and Cancer

Ana I. Robles and Curtis C. Harris

For additional articles in this collection, see http://cshperspectives.cshlp.org/cgi/collection/

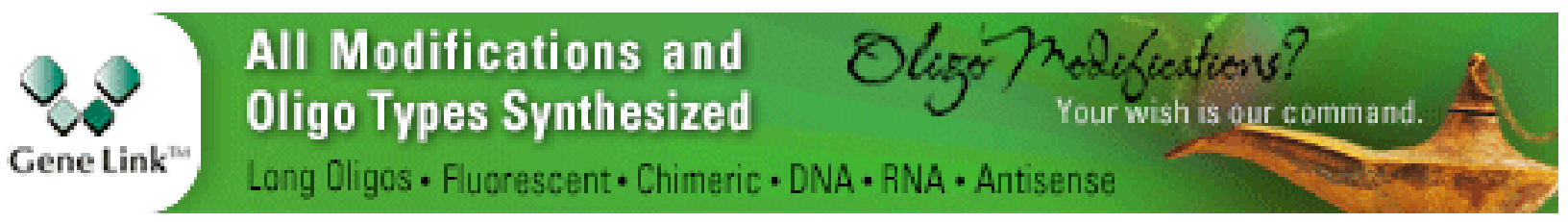

Copyright @ 2009 Cold Spring Harbor Laboratory Press; all rights reserved 